\title{
Composition and biomass of phytoplankton assemblages in coastal Antarctic waters: a comparison of chemotaxonomic and microscopic analyses
}

\author{
Irene A. Garibotti ${ }^{1, *}$, María Vernet ${ }^{2}$, Wendy A. Kozlowski ${ }^{2}$, Martha E. Ferrario ${ }^{3}$ \\ ${ }^{1}$ Instituto Argentino de Nivología, Glaciología y Ciencias Ambientales, CRICYT, CONICET, C.C. 330, \\ 5500 Mendoza, Argentina \\ ${ }^{2}$ Marine Research Division, Scripps Institute of Oceanography, University of California San Diego, La Jolla, \\ California 92093-0218, USA
}

${ }^{3}$ División de Ficología, Facultad de Ciencias Naturales y Museo, Universidad Nacional de La Plata, 1900 La Plata, Argentina

\begin{abstract}
We describe the distribution of phytoplanktonic community composition and biomass from the Western Antarctic Peninsula coast (between $64^{\circ}$ and $68^{\circ} \mathrm{S}$ ) using 2 analytical techniques: microscopy and HPLC of photosynthetic pigments. Phytoplankton biomass was estimated as chlorophyll a (chl a) by HPLC and chemotaxonomic quantification of microalgae biomass was performed by multiple regression analysis of pigment concentrations. For the estimation of chl a: diagnostic pigment ratios, it was found of primary importance to differentiate between phytoplankton assemblages within the study area. Three assemblages were differentiated according to their total standing stock and analyzed independently. Phytoplankton biomass was also estimated as carbon (C) concentration by microscopic analysis of cell abundance and biovolumes. Microscopy and chemotaxonomy give a high level of agreement for phytoplankton characterization, showing an on/offshore gradient, with high diatom and cryptophyte biomass in coastal waters, and a mixed assemblage with low biomass in open waters. This gradient was not observed in total cell abundance, indicating that the biomass gradient is controlled by cell size. Microscopy also showed shifts in diatom species throughout the area. $\mathrm{C}$ and $\mathrm{chl}$ a biomass estimates for the individual microalgae groups were strongly correlated for cryptophytes, chlorophytes and most diatoms, but did poorly for dinoflagellates, prymnesiophytes and chrysophytes. From this study, we conclude that both microscopy and chemotaxonomy can be used to accurately characterize phytoplankton assemblages, but some limitations are present in both techniques. Based on phytoplankton C concentrations, we estimated an average in situ growth rate of $0.28 \mathrm{~d}^{-1}$. In situ cell C:chl a ratios had high variability (from 40 to 220) and were non-linearly related to sample growth rates. Significant differences were found among average $\mathrm{C}$ :chl a ratios of low $\left(<1 \mu \mathrm{g} \mathrm{chl} \mathrm{al}^{-1}\right)$ and high biomass communities $\left(>1 \mu \mathrm{g} \mathrm{chl} \mathrm{a} \mathrm{l}^{-1}\right)$, with values of

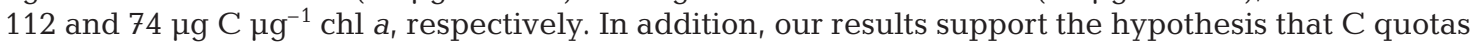
of diatoms and other microalgae do not differ greatly from each other, as previously believed.
\end{abstract}

KEY WORDS: Phytoplankton composition · Microscopy $\cdot$ Chemotaxonomy $\cdot$ Photosynthetic pigments · Western Antarctic Peninsula

\section{INTRODUCTION}

The phytoplanktonic community plays a crucial role in marine ecosystems, affecting the nutrient cycling, the structure and efficiency of the food web and the flux of particles to deep waters (Smith \& Sakshaug

*Email: ireneg@lab.cricyt.edu.ar
1990, Priddle et al. 1992). Thus, phytoplankton composition and biomass estimation is of major importance to understanding the structure and dynamics of the ecosystem. Microscopy has been the classical method to study phytoplankton. Microscopic examination of water samples involves the identification and estima- 
tion of cell abundance and biovolume (Utermöhl 1958, Booth 1993, Hillebrand et al. 1999). Carbon (C) phytoplankton standing stock is calculated from cell biovolume estimates using published values of $\mathrm{C}$ per cell volume (Strathmann 1967, Montagnes et al. 1994, Menden-Deuer \& Lessard 2000, Montagnes \& Franklin 2001). Although light microscopy allows for species identification, it is a time consuming technique that requires a highly trained observer. Furthermore, this technique could be imprecise for small flagellate quantification which may not survive sample fixation, whose taxonomy is poorly known and whose trophic state cannot be distinguished (Reid 1983, Hewes et al. 1984, Booth 1993).

Alternatively, analysis of water samples by HPLC allows for phytoplankton characterization by chemotaxonomic study of photosynthetic pigments. Total phytoplankton standing stock is estimated as chlorophyll a (chl a) concentration and algae classes are identified from the presence of diagnostic carotenoid pigments. Furthermore, the biomass of each taxon is calculated as a proportion of total chl a using chl a:carotenoid pigment ratios (Wright \& Jeffrey 1987, Wright et al. 1991, Millie et al. 1993, Jeffrey et al. 1999). For this purpose, 2 approaches are mostly used: either each algal class is characterized by its main carotenoid pigment and pigment ratios are estimated using multiple linear regression analysis (Gieskes et al. 1988), or each class is characterized with a suite of diagnostic pigments and its biomass is estimated from proposed pigment ratios using a pigment matrix factorization method, such as the CHEMTAX program (Mackey et al. 1996). Since a pigment assigned as marker of one phytoplankton class can be present as a secondary pigment in other algae, the matrix factorization method improves phytoplankton identification. However, this approach is somewhat limited as it requires previous knowledge of taxonomic composition and pigment ratios of the samples under analysis (Jeffrey et al. 1999). Thus, multiple regression analysis continues to be a widespread technique in field studies (Moline et al. 2000, Prézelin et al. 2000, Ross et al. 2000, Marty et al. 2002). Chemotaxonomic sample analysis requires only a short time and the results are reproducible; however, its major limitation is that cell pigment ratios change with growth conditions and species composition (Schlüter et al. 2000), introducing uncertainty in biomass quantification.

Comparisons of microscopic and chemotaxonomic techniques of phytoplankton identification have demonstrated that HPLC pigment analysis is a valuable tool for phytoplankton studies (Buma et al. 1990, Tester et al. 1995, Bidigare et al. 1996, Wright et al. 1996, Havens et al. 1999, Schlüter et al. 2000, Rodriguez et al. 2002). However, most of these comparisons were based only on cell abundance, which cannot be considered a measure of phytoplankton biomass. Furthermore, only general characteristics of the phytoplankton community structure have been compared, such as the relative importance of different microalgae classes, or the spatial and seasonal changes of major groups. Few attempts have been made to compare phytoplankton $\mathrm{C}$ and chl a measurements by correlation analyses. Therefore, further research is necessary to assert whether microscopic and chemotaxonomic biomass estimates are comparable, and in this way to test the accuracy of chemotaxonomy.

HPLC pigment analysis measures phytoplankton biomass as chl a concentration, which is an estimation of the biomass photosynthetically active for primary production. Other methods that measure chl a concentration, such as chl a remote sensing from satellite or continuous in vivo chl a fluorescence measurements, are very auspicious for phytoplankton study, permitting an intensive spatial documentation of phytoplankton distribution over large areas of the oceans. Although biomass estimates such as $\mathrm{C}$ and chl a concentrations can both be used to characterize the phytoplanktonic community, C quantification is essential to calculate phytoplankton growth rates, to study aquatic food webs, and to model the flux of organic matter in marine ecosystems. Thus, to take advantage of the information obtained with these techniques, it has been proposed to convert chl a biomass into C biomass using C:chl a ratios (Smith \& Sakshaug 1990, Geider et al. 1997). The analysis of natural phytoplankton assemblages using different techniques is fundamental for the calculation of this ratio, and the comparison of microscopic and HPLC analyses is an excellent opportunity to estimate in situ C:chl a ratios.

The aim of the present study is to assess the usefulness of chemotaxonomy as a tool to estimate phytoplankton composition and biomass. For this purpose, composition and biomass of the phytoplankton community of an area off the Western Antarctic Peninsula (see Fig. 1) is described using and comparing microscopy and chemotaxonomy. Our main question is whether these methodologies are comparable and suitable to characterize phytoplankton assemblages. Furthermore, we test the usefulness of the multiple regression approach for chemotaxonomic phytoplankton study under variable environmental conditions. Since our study area is highly variable, includes coastal and continental shelf zones, and is affected by the seasonal advance and retreat of sea ice cover (Baker et al. 1996), we could expect pigment ratio changes within the area. Pigment data variability is analyzed in an ecological and oceanographic context. The present research is part of the Palmer Long-Term Ecological Research (LTER) project (Baker et al. 1996), 
which includes phytoplankton surveys from ships and also remote sensing from satellite. Therefore, estimations of $\mathrm{C}$ and chl a biomass performed by microscopy and HPLC are used to calculate in situ C:chl a ratios that may be used for phytoplankton quantification from remote sensing data. Finally, a comparison of results is used to review methodological controversies about diatom and other phytoplankter cell C quotas, as well as to assess in situ growth rates.

\section{MATERIALS AND METHODS}

Sampling and study area. The study area is located on the continental shelf west of the Antarctic Peninsula, between $64^{\circ}$ and $68^{\circ} \mathrm{S}$ and from the coast to $200 \mathrm{~km}$ off-shore (Fig. 1). Sampling was performed on board the RV 'Polar Duke' between January 8 and February 10, 1996. A total of 58 stations were sampled along 5 cross-shelf transect lines (Waters \& Smith 1992). Conductivity temperature depth (CTD) measurements were obtained using a Sea Bird CTD system (SBE 9/11) and bio-optical physical vertical profiles were made with a Biospherical Instruments MER 2040 system. Discrete water samples were collected at 6 depths within the euphotic layer using $10 \mathrm{l}$ Go-Flow bottles attached to a General Oceanics rosette.

Microscopic analyses. For quantitative microscopic analyses, water aliquots were sampled from the $50 \%$ incident photosynthetically active radiation (PAR) depth within the mixed layer and preserved with $2 \%$ acid Lugol's iodine solution. Phytoplankton cells were identified and counted with an inverted microscope (Iroscope IS-PH), according to the Utermöhl method (Utermöhl 1958). Linear cell dimensions were measured using the geometric shapes proposed by Hillebrand et al. (1999) and unidentified phytoflagellates were calculated as spheres or prolate spheroids. The number of cells measured was variable, depending on their abundance in the samples (ranging from 20 to more than 500 cells). Mean biovolume of each genera or phytoplankton group, differentiated also into size fractions $(<10,20$, 40,100 and $>100 \mu \mathrm{m}$ ), was calculated from the mean value of their dimensions. Biovolumes were corrected to account for the cell shrinkage due to sample fixation using the formula proposed by Montagnes et al. (1994). While the effect of sample fixation on cell volume can be variable (Menden-Deuer et al. 2001), the correction factor measured by Montagnes et al. (1994) can be consid- ered as an average value for a mixed phytoplankton community. Cell $\mathrm{C}$ content was calculated using 2 carbon to volume quotas: one for diatoms (Montagnes \& Franklin 2001) and one for all other algae groups (Montagnes et al. 1994). These conversion equations were chosen because they are based on cell volume and abundance measurements made using similar procedures to ours. Sample carbon concentrations (C) were calculated from cell composition, abundance and C content per cell. Additionally, we applied the carbon to biovolume equations of Strathmann (1967) to calculate sample C concentrations $\left(\mathrm{C}_{\mathrm{S}}\right)$, in order to compare the biomass estimates obtained using different conversion factors.

Chemotaxonomic analyses. For pigment analysis by HPLC, water aliquots were filtered onto Whatman glass fiber filters $(\mathrm{GF} / \mathrm{F})$ and frozen at $-80^{\circ} \mathrm{C}$ for at least $24 \mathrm{~h}$. Pigments were extracted with $90 \%$ acetone for $24 \mathrm{~h}$ and subsequently filtered onto $0.2 \mu \mathrm{m}$ membrane filters. Samples were injected onto a reverse phase column (Waters Resolve C-18; $300 \times 3.9$ mm, $5 \mu \mathrm{m}$ ) and analyzed according to the method of Wright et al. (1991) with minor modifications. Pigments were detected at $440 \mathrm{~nm}$, and peaks were identified and quantified by comparing their retention times and peak areas with pure pigment standards.

Chl a concentration was taken as an indicator of the total phytoplankton biomass. The carotenoid pigments selected as chemotaxonomic markers of microalgae classes were: fucoxanthin for diatoms, peridinin for di-

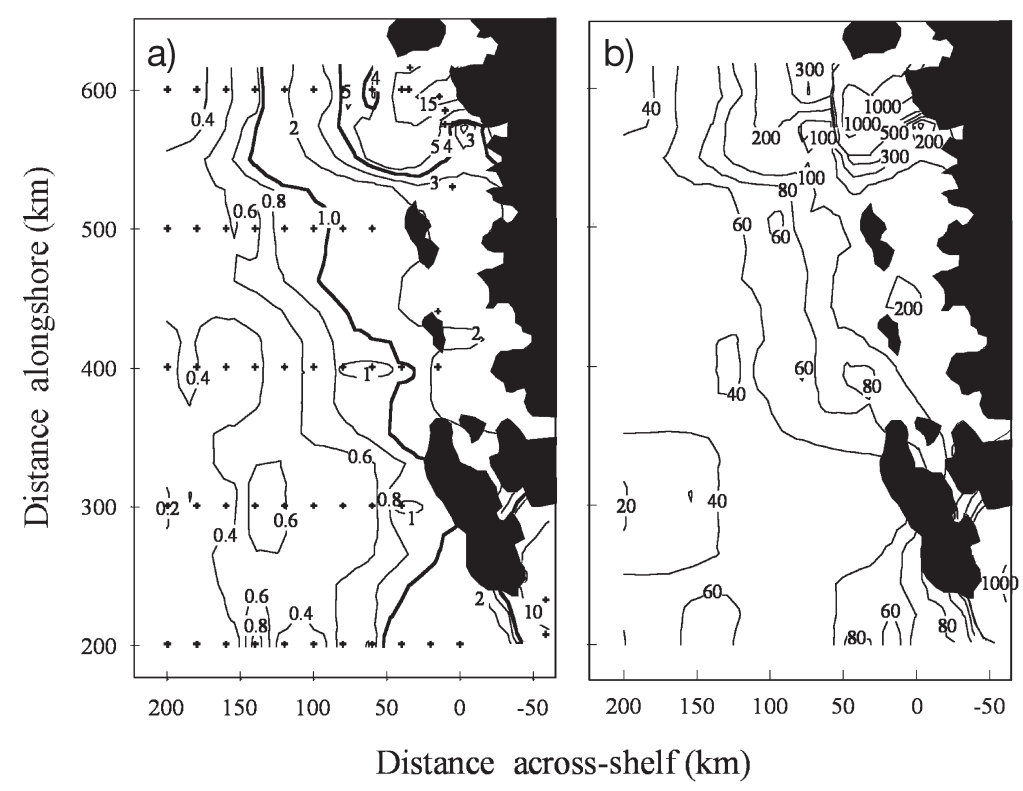

Fig. 1. Phytoplankton biomass distribution off the Western Antarctic Peninsula. (a) Mean chl a concentration in the euphotic layer $\left(\mu \mathrm{g} \mathrm{l} \mathrm{l}^{-1}\right)$ and (b) phytoplankton $\mathrm{C}$ concentration near surface $\left(\mu \mathrm{g} \mathrm{l}^{-1}\right)$. (+) Station location.

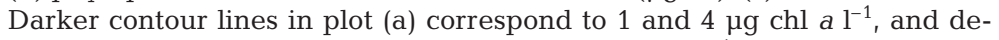
marcate 3 regions within the study area: low $\left(<1 \mu \mathrm{g} \mathrm{l}^{-1}\right)$, intermediate $(1$ to $\left.4 \mu \mathrm{g} \mathrm{l}^{-1}\right)$ and high biomass region $\left(>4 \mu \mathrm{g} \mathrm{l}^{-1}\right)$ 


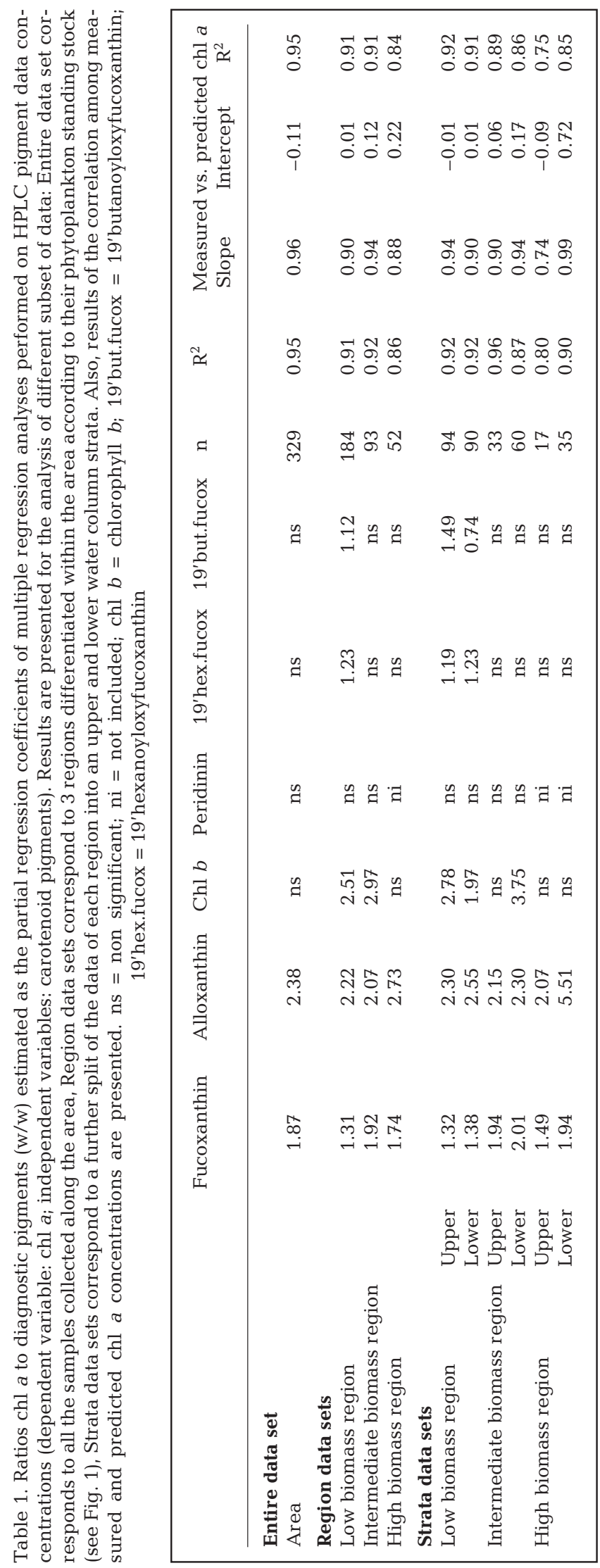

noflagellates, alloxanthin for cryptophytes, 19'-hexanoyloxyfucoxanthin for prymnesiophytes, 19'-butanoyloxyfucoxanthin for pelagophytes and chl $b$ for chlorophytes. These are the more abundant microalgal classes in the area (Moline et al. 2000, Prézelin et al. 2000, Ross et al. 2000, Rodriguez et al. 2002). Chl a (dependent variable) and diagnostic pigment data (independent variables) were analyzed by multiple linear regression analyses. The approach used to apply multiple regressions is detailed in the first section of 'Results and discussion'. The significant partial regression coefficients estimated were used as chl a:diagnostic pigment ratios to calculate the biomass of each microalgal group as a proportion of total phytoplankton biomass (Gieskes et al. 1988). To evaluate the power of the regressions for phytoplankton biomass estimation, simple linear correlations were fitted between measured chl $a$ concentration and the sum of the chl a contributed by all microalgae classes (predicted chl a).

Growth rates. Population growth rates were calculated as C-specific accumulation rate, $\mu=1 / t \ln \left[\left(\mathrm{C}_{0}+\right.\right.$ $\left.\mathrm{C}_{t}\right) / \mathrm{C}_{0}$ ], where $\mathrm{C}_{0}=$ sample $\mathrm{C}$ content microscopically measured, $\mathrm{C}_{t}=\mathrm{C}$ fixed during incubation and $t=$ incubation time. Simulated in situ incubations were set up to measure inorganic carbon uptake. Duplicate samples were estimated for each light level by $24 \mathrm{~h}$ incubations with ${ }^{14} \mathrm{C}$-sodium bicarbonate (see Dierssen et al. 2000 for details on methods). Technical problems prevented the measurement of primary productivity in all samples; hence, data are only for 39 stations.

Data analysis. The depth of the upper mixed layer (UML) was determined from sigma-t $\left(\sigma_{t}\right)$ vertical profiles, as the depth where a change of $\sigma_{t}>0.05$ over $5 \mathrm{~m}$ depth interval occurred.

Chl a biomass concentration of each discrete sample was calculated as the average of the 6 depths taken within the euphotic zone. These values were used to distinguish 3 groups of stations, defined as low, intermediate and high biomass regions (Fig. 1). Phytoplankton community biomass concentrations estimated as $\mathrm{C}$ and as chl a for each station (microscopic and HPLC results, respectively) were compared by simple linear correlations. Tests for differences between means were performed using a paired $t$-test. The level of significance was set as $\mathrm{p}<0.01$ for all statistical analyses.

\section{RESULTS AND DISCUSSION}

\section{Estimation of phytoplankton biomass from pigment signatures}

Exploratory analysis of the chl a spatial distribution showed that the phytoplanktonic community of the study area was highly variable. A gradient in chl a con- 
centration was found across-shelf, with maximum concentrations in coastal waters (Fig. 1a). This seems to be a stable pattern for the area, as it was found throughout successive years by Smith et al. (1996). A multiple linear regression between chl a and diagnostic pigment concentrations showed that chl a distribution was closely related to alloxanthin and fucoxanthin (Table 1; entire data set). Biomass estimation using the partial regression coefficients of this regression indicated that cryptophytes and diatoms accounted for most of the autotrophic biomass of the area (Table 2; entire data set). It is considered that if the relationship between measured and predicted chl $a$ is significant and strong, the fitted regression model has high predictive power of phytoplankton biomass (Havens et al. 1999, Moline et al. 2000, Prézelin et al. 2000). Thus, the close correlation that we obtained between measured chl $a$ and the sum of chl a contributed by diatoms and cryptophytes (Table 1; entire data set) suggests that phytoplankton was accurately estimated with the fitted multiple regression.

However, further examination of predicted chl a concentration for discrete samples denoted model deficiencies. Fig. 2 shows that the regression was influenced by very high chl a values found in a few samples. Furthermore, most of the samples distributed near the origin of the plot fell above the unity line (Fig. 2; inset plot), indicating that they were overestimated. These samples with low biomass represent vast regions within the study area. Thus, it can be concluded that a high correlation between predicted and measured chl a concentration was not demonstrative of the accuracy of the multiple regression equation for phytoplankton prediction.

Examining the distribution of predicted chl $a$ in relation to the unity line, samples were grouped in 3 major clusters (Fig. 2): stations with $<1 \mu \mathrm{g}$ chl a $\mathrm{l}^{-1}$ which were overestimated, stations with 1 to $4 \mu \mathrm{g} \operatorname{chl}$ a $\mathrm{l}^{-1}$ which scattered randomly above and below the unity line, and a few stations with $>4 \mu \mathrm{g} \mathrm{chl} \mathrm{a} \mathrm{l}^{-1}$ which dominated the regression. Since predicted chl a concentrations are calculated from the contributions of caro-

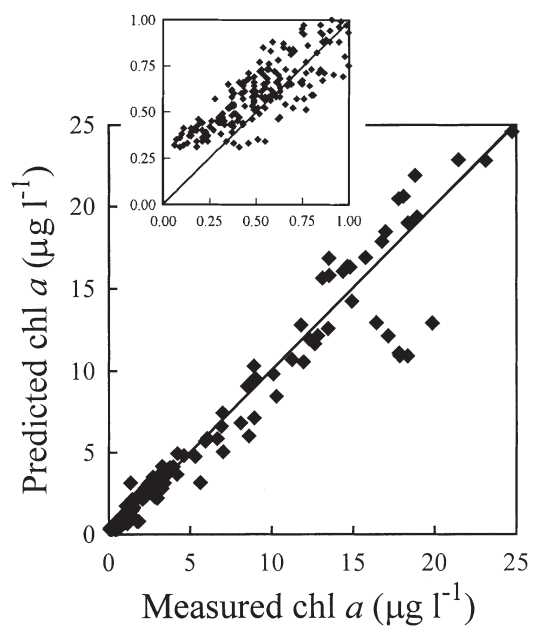

Fig. 2. Measured chl a concentration against chl a concentration predicted by a multiple regression analysis performed on the HPLC pigment data of all the samples collected along the study area (dependent variable: chl $a_{\text {; }}$ independent variables: carotenoid pigments). Inset: detail of the plot for values lower

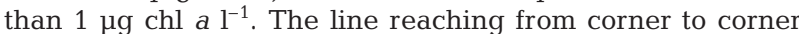
represents unity. Correlation statistics are given in Table 1

tenoid pigments, changes in the deviation pattern of predicted from expected chl a concentrations may reflect groups of stations with different pigment composition. Therefore, to improve the multiple regression analysis, we propose as a convenient approach to analyze these 3 groups of stations independently.

Based on the previous results, 3 regions were differentiated within the area according to station average water column chl a concentration: Low biomass, $<1 \mu \mathrm{g}$

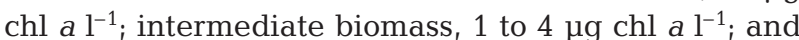
high biomass, $>4 \mu \mathrm{g} \mathrm{chl} \mathrm{a} \mathrm{l}^{-1}$ regions (Fig. 1a). Multiple regressions were fitted to the pigment data subsets of these regions, excluding peridinin from the high biomass region since it was detected at only 2 sampling stations. Relationships among chl a and diagnostic pigment concentrations were significant and high for all regions (Table 1 ; region data sets). The accuracy of these regression equations to analyze phytoplankton

Table 2. Concentration of the diagnostic pigments of the individual microalgae classes measured by HPLC, and chl a biomass associated to each pigment calculated applying to different subset of data the pigment ratios of Table 1. Total chl a concentration was predicted by the sum of chl a contributed by each diagnostic pigments. Values averaged over the study area \pm SD

\begin{tabular}{|c|c|c|c|c|c|c|c|}
\hline & Fucoxanthin & Alloxanthin & Chl $b$ & Peridinin & 19'hex.fucox & 19 'but.fucox & Chl a \\
\hline \multicolumn{8}{|c|}{ Diagnostic pigment concentrations $\left(\mu \mathrm{g} \mathrm{l}^{-1}\right)$} \\
\hline & $1.13 \pm 2.42$ & $0.12 \pm 0.26$ & $0.07 \pm 0.10$ & $0.04 \pm 0.04$ & $0.09 \pm 0.04$ & $0.04 \pm 0.03$ & $2.61 \pm 4.60$ \\
\hline \multicolumn{8}{|c|}{ Proportion of chl a concentration $\left(\mu \mathrm{g} \mathrm{l}^{-1}\right)$} \\
\hline Entire data set & $2.11 \pm 4.46$ & $0.31 \pm 0.94$ & 0 & 0 & 0 & 0 & $2.41 \pm 4.61$ \\
\hline Region data sets & $1.95 \pm 4.16$ & $0.30 \pm 0.97$ & $0.08 \pm 0.15$ & 0 & $0.06 \pm 0.07$ & $0.03 \pm 0.03$ & $2.42 \pm 4.30$ \\
\hline Strata data sets & $2.00 \pm 4.32$ & $0.33 \pm 0.92$ & $0.06 \pm 0.10$ & 0 & $0.06 \pm 0.07$ & $0.03 \pm 0.04$ & $2.48 \pm 4.48$ \\
\hline
\end{tabular}



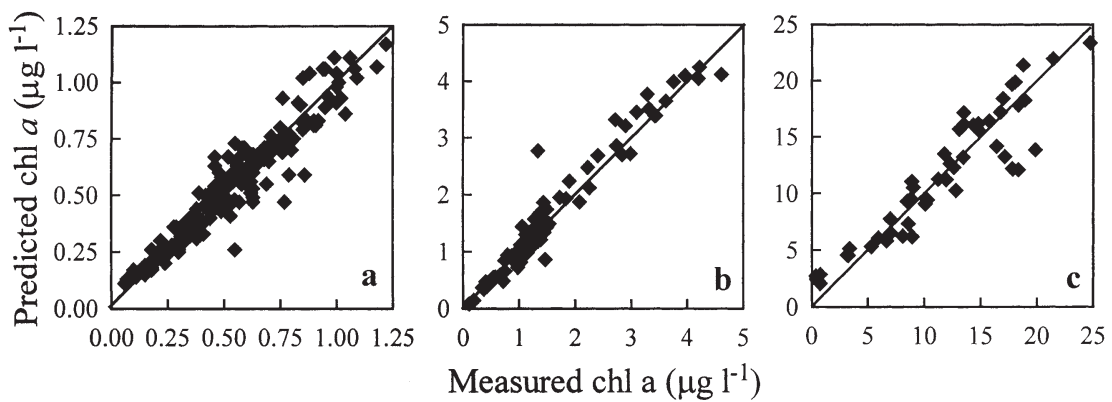

Fig. 3. Measured chl a concentration against chl a concentration predicted by a multiple regression analysis of HPLC pigment data at 3 regions within the study area. Regions as in Fig. 1. (a) Low biomass region, (b) intermediate biomass region, (c) high biomass region. The line reaching from corner to corner represents unity. Correlation statistics are given in Table 1

was confirmed by the significant and strong correlation found between measured and predicted chl $a$, and the random distribution of stations around the unity line (Fig. 3, Table 1). These results show that the limitations detected analyzing the entire data set were overcome. Measured and predicted chl a concentrations for each region are shown in Table 3.

The regression equations showed differences in significant pigments and partial regression coefficients, suggesting the presence of distinct phytoplankton assemblages within the study area (Table 1 ; region data sets). Within the low biomass region, 5 of the 6 pigments analyzed contributed to explain chl $a$, indicating a mixed phytoplankton community. Within the intermediate biomass region, fucoxanthin, alloxanthin and chl $b$ were the most important pigments, reflecting a high contribution of diatoms, cryptophytes and chlorophytes. Within the high biomass region, fucoxanthin and alloxanthin denoted dominance of diatoms and high contribution of cryptophytes, respectively. Partial regression coefficients of these equations are close to the chl a to diagnostic pigment ratios reported as typical for the different algal classes in cul- tured assemblages (Gieskes et al. 1988, Sosik \& Mitchell 1991, Buma et al. 1992, Schlüter et al. 2000). Their values vary from 0.7 to 3.95 , suggesting that the pigment ratios in the field are an accurate representation of the dominant taxa. In addition, these coefficients are similar to the pigment ratios used previously for phytoplankton biomass estimation in the Western Antarctic Peninsula (Bidigare et al. 1996, Ross et al. 2000, Rodriguez et al. 2002). In contrast, Prézelin et al. (2000) determined a wider range of pigment ratios for the same area $(0.1$ to 14 chl a: carotenoid), quite distant from those reported from natural or cultured microalgae assemblages. Thus, we consider that the partial regression coefficients estimated in this study are appropriate as pigment ratios, and were used to calculate the biomass of individual algae classes within each region (Table 2 ; region data sets).

Phytoplanktonic community composition predicted in this way is remarkably different from that predicted using the entire data set (Table 2). In particular, it was detected that the contribution of many different algal classes had been previously overlooked, and that these algae accounted for up to $80 \%$ of the total chl a biomass of some stations. Otherwise biomass of these microalgae was assigned as belonging to diatoms and cryptophytes, resulting in biomass overestimation of these taxa. Phytoplankton characterization of our study area was certainly improved by independent analysis of the different algae assemblages, revealing a diverse phytoplanktonic community within the area. The 3 phytoplankton assemblages had differences in their total standing stock, increasing the evidence that changes in phytoplankton communities biomass are associated with compositional shifts (Claustre 1994,

Table 3. Phytoplankton community standing stock quantified as: chl a concentration measured by HPLC; chl a concentration predicted by multiple regression analyses of pigment data as in Table 2; cell abundance measured under the microscope; carbon concentrations (C) measured by microscopy using the cell carbon per volume ratios proposed by Montagnes \& Franklin (2001) and Montagnes et al. (1994) for diatoms and other protist phytoplankton, respectively; and carbon concentrations $\left(\mathrm{C}_{\mathrm{S}}\right)$ measured by microscopy using the cell carbon per volume ratios proposed by Strathmann (1967). Values \pm SD averaged over the entire study area and in 3 regions differentiated as in Fig. 1

\begin{tabular}{|lccccc|}
\hline & $\begin{array}{c}\text { Measured } \\
\text { chl } a \\
\left(\mu \mathrm{I} \mathrm{l}^{-1}\right)\end{array}$ & $\begin{array}{c}\text { Predicted } \\
\mathrm{chl} a \\
\left(\mu g \mathrm{l}^{-1}\right)\end{array}$ & $\begin{array}{c}\text { Cell } \\
\text { abundance } \\
\left(\times 10^{4} \mathrm{l}^{-1}\right)\end{array}$ & $\begin{array}{c}\text { Carbon } \\
\text { concentration } \\
\left(\mu \mathrm{C} \mathrm{l}^{-1}\right)\end{array}$ & $\begin{array}{c}\text { Carbon according to } \\
\text { Strathmann }(1967) \\
\left(\mu \mathrm{g} \mathrm{C} \mathrm{C}^{-1}\right)\end{array}$ \\
\hline Entire area & $2.61 \pm 4.60$ & $2.42 \pm 4.30$ & $486 \pm 279$ & $181.0 \pm 290.3$ & $102.6 \pm 104.6$ \\
Low biomass region & $0.53 \pm 0.23$ & $0.49 \pm 0.22$ & $446 \pm 156$ & $49.6 \pm 16.0$ & $50.0 \pm 17.1$ \\
Intermediate biomass region & $1.64 \pm 0.74$ & $1.62 \pm 0.74$ & $544 \pm 440$ & $122.4 \pm 79.0$ & $105.3 \pm 97.4$ \\
High biomass region & $11.70 \pm 5.73$ & $10.65 \pm 5.71$ & $538 \pm 314$ & $752.3 \pm 356.7$ & $288.8 \pm 90.0$ \\
\hline
\end{tabular}


Bidigare et al. 1996, Varela et al. 2002). Although the chl a concentrations used can be considered arbitrary, results of the entire data set analysis provided us with a first insight to set chl a limits, which agree with previous studies in the Southern Ocean that reported distinct communities associated with similar chl a ranges (Buma et al. 1992, Jacques \& Panouse 1991, Villafañe et al. 1995, Moline et al. 1997, among others).

Analysis of pigment data is only suitable for the quantitative study of the phytoplankton if pigment ratios can be assumed as constant (Gieskes et al. 1988). Cellular pigment concentration can change in response to environmental factors, biasing the biomass quantification based on fixed pigment ratios (Lami et al. 1992, Van Leeuwe et al. 1998, Schlüter et al. 2000). For example, variations in cell light regime due to mixing of the water column can be important in our area (Smith et al. 1996) and we could expect changes in pigment ratios due to this feature. Further analysis of our data showed a close relationship between total phytoplankton standing stock and mixed layer depth, as found previously for other areas of the Western Antarctic Peninsula (Mitchell \& Holm-Hansen 1991). In consequence, the 3 regions, as discriminated by their chl a concentration, grouped stations with similar water column physical characteristics. The low biomass region had a small density gradient with depth and a deep or not obvious mixed layer (UML $>35 \mathrm{~m}$ ) (Fig. 4a). The intermediate biomass region had an evident stratification and a shallower mixed layer depth (UML $<30 \mathrm{~m}$ ) (Fig. 4b). The high biomass region had a steep density gradient near the surface and strong water column stratification (Fig. 4c). The homogeneity of the water column physical structure suggests no variations in the cell light regime within regions, and led us to assume that within each region, algal cells should have been exposed to similar average light conditions. Therefore, the pigment ratios previously estimated for each region should not be expected to vary due to cell light regime.

Changes in cell pigment ratios could also be expected throughout the water column due to light intensity and quality variations with depth. To test this hypothesis, pigment data of each region were divided into an upper and lower water column strata (above and below $50 \%$ PAR depth, respectively). Chl $a$ to diagnostic pigment multiple regressions were significant and strong for all subsets of data (Table 1; strata data sets). Furthermore, measured and predicted chl a concentrations were closely related (Table 1) and did not evidence model deficiencies, indicating accuracy of the regression equations to predict phytoplankton. While differences in significant pigments and their partial regression coefficients suggest some microalgae shifts and changes in their pigmentation with depth (Table 1), several of the partial regression coefficients (i.e. those estimated for alloxanthin, chl $b$ and 19'-butanoyloxyfucoxanthin) are far from pigment ratios reported as typical for their respective microalgae classes (Gieskes et al. 1988, Sosik \& Mitchell 1991, Bidigare et al. 1996, Schlüter et al. 2000), and we interpret that their use as pigment ratios may not be valid. An explanation could be that the lower number of samples per group adversely affected regressions. Nevertheless, their use for biomass concentration estimation showed nearly identical average values to the calculated ones regardless of different depth strata (Table 2; region and strata data sets). Thus, it can be concluded that pigment changes due to light variation with depth had a minor influence on microalgal biomass estimation of this area, as mentioned before for the same area (Ross et al. 2000) and for algal cultures (Schlüter et al. 2000).

In summary, we did not find evidence of changes in cell pigment ratios due to light variations in the 3 phytoplankton assemblages differentiated, and this result may be expected in other areas as well since phytoplankton growth is closely associated to local environmental conditions (Smith \& Sakshaug 1990). Thus, when analyzing phytoplanktonic community composition and biomass from pigment signatures, it is of primary importance to differentiate the phytoplankton assemblages present within the area. This is an alternative approach to the use of a suite of regressions to predict the phytoplankton of large areas, delimiting regions according to some environmental conditions considered to influence phytoplankton pigment ratio variability (Gieskes et al. 1988, Havens et al. 1999, Prézelin et al. 2000). According to these results, phytoplankton biomass concentrations reported in the rest of this paper correspond to those estimated from the 3 regions.

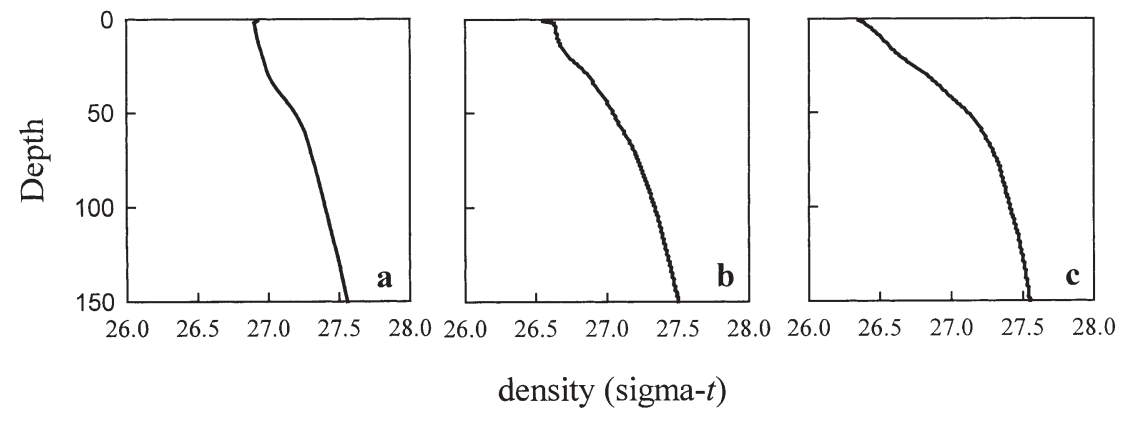

Fig. 4. Vertical distribution patterns of water column density averaged over all stations within the 3 regions differentiated as in Fig. 1. (a) Low biomass region, (b) intermediate biomass region, (c) high biomass region 


\section{Phytoplankton carbon estimates from microscopy}

Microscopic analysis showed that the phytoplankton community of the study area was highly variable in cell abundance and carbon biomass (Table 3). Small unidentified phytoflagellates $(<15 \mu \mathrm{m})$ numerically dominated the community, followed by cryptophytes

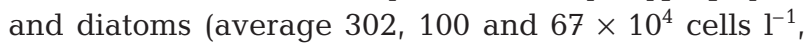
respectively). Diatoms accounted for the highest proportion of autotrophic biomass, and cryptophytes and unidentified phytoflagellates made smaller contributions (Table 4). Other groups identified were dinoflagellates, chlorophytes (including prasinophyceae and chlorophyceae), prymnesiophytes and chrysophytes.

A gradient in C concentration was found acrossshelf, with maximum values in restricted coastal regions (Fig. 1b). The low, intermediate and high biomass regions, as delimited in the previous section, had similar phytoplanktonic cell abundance, but substantial differences in $\mathrm{C}$ standing stock (Table 3). These results indicate that differences in cell size between coastal and offshore assemblages account for the gradient in $\mathrm{C}$ concentrations, and highlight the importance of measuring cell volume to account for biomass standing stock.

Nanoplanktonic algae dominated the low biomass region (comprising $80 \%$ of total carbon biomass), and were mostly unidentified phytoflagellates, diatoms, dinoflagellates and cryptophytes (Table 4). Small centric and pennate diatoms $(<15 \mu \mathrm{m})$ of Thalassiosira spp. and Fragilariopsis curta, F. cylindrus and F. pseudonana represented $67 \%$ of diatom carbon. The presence of this assemblage in pelagic waters is described as typical of the entire Southern Ocean (Von Bröckel 1981).

Nanoplanktonic algae also dominated the intermediate biomass region (comprising $65 \%$ of carbon bio- mass). Diatoms and cryptophytes predominated in the assemblage, and unidentified flagellates and dinoflagellates were also important (Table 4). Diatom species with higher contribution to diatom C were Odontella weissflogii (18\% C), Actinocyclus sp. (9\% C), Pseudonitzschia spp. (8\% C), Eucampia antarctica (6\% C) and Thalassiosira spp. (6\% C), and nanoplanktonic species of Thalassiosira spp. (18\% C) and Fragilariopsis spp. $(12 \%$ C). The prymnesiophyte Phaeocystis spp. had low contribution to $\mathrm{C}$ biomass, but high cell abundance

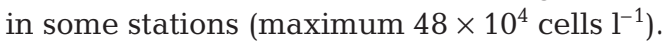

In contrast, the high biomass region was characterized by dominance of the microphytoplankton size fraction (comprising $86 \%$ of $\mathrm{C}$ biomass). Diatoms accounted for the major proportion of autotrophic biomass (Table 4), with Odontella weissflogii, Eucampia antarctica and an unidentified centric species $(<100 \mu \mathrm{m})$ representing $83 \%$ of diatom $\mathrm{C}$. This region encompassed 2 different sites (Fig. 1b). In Marguerite Bay (in the southeast of the study area), diatoms dominated the phytoplankton assemblage and Phaeocystis spp. made a minor contribution to

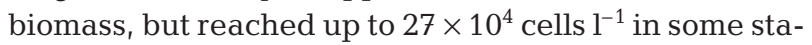
tions. This community was associated with the ice edge which was present in the southern part of Marguerite Bay during the sampling period (Vernet \& Baker 1996). South of Anvers Island (in the northeast of the study area), diatoms and cryptophytes co-dominated the assemblage (maximum $174 \times 10^{4}$ cells $^{-1}$ and $1756 \mu \mathrm{g} \mathrm{Cl}^{-1}$

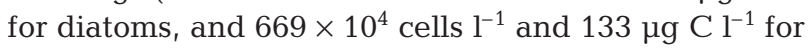
cryptophytes). Furthermore, at this site, Pyramimonas spp. reached the highest biomass over the entire study area (maximum $18 \mu \mathrm{g} \mathrm{C}^{-1}$ ). A similar assemblage has been documented in other coastal regions of the Western Antarctic Peninsula, such as the Gerlache Strait. In addition, diatoms and cryptophytes have also been reported as the main bloom-forming microalgae of the

Table 4. Biomass of the individual microalgal groups estimated as carbon (C) from microscopic examination and as chl a from their diagnostic pigment concentrations measured by HPLC. Phytoflagellates not identified under the microscope were grouped and their carbon biomass is reported. Values \pm SD averaged over the entire study area and in 3 regions differentiated as in Fig. 1

\begin{tabular}{|c|c|c|c|c|c|c|c|}
\hline & Diatoms & Cryptophytes & Chlorophytes & Dinophytes & $\begin{array}{l}\text { Prymnesio- } \\
\text { phytes }\end{array}$ & Chrysophytes & $\begin{array}{c}\text { Unidentified } \\
\text { phytoflagellates }\end{array}$ \\
\hline \multicolumn{8}{|l|}{ Entire area } \\
\hline$\left(\mu \mathrm{g} C \mathrm{l}^{-1}\right)$ & $130.0 \pm 291.1$ & $\begin{array}{ll}1 & 19.2 \pm 42.8\end{array}$ & $0.8 \pm 2.6$ & $8.6 \pm 8.1$ & $0.2 \pm 0.8$ & $1.1 \pm 3.6$ & $17.2 \pm 8.7$ \\
\hline$\left(\mu \mathrm{gchl} a \mathrm{l}^{-1}\right)$ & $1.95 \pm 4.16$ & $0.30 \pm 0.97$ & $0.08 \pm 0.15$ & 0 & $0.06 \pm 0.07$ & $0.03 \pm 0.03$ & \\
\hline \multicolumn{8}{|c|}{ Low biomass region } \\
\hline$\left(\mu \mathrm{g} \mathrm{Cl}^{-1}\right)$ & $11.2 \pm 6.1$ & $6.9 \pm 7.5$ & $0.3 \pm 0.5$ & $9.2 \pm 9.2$ & $0.0 \pm 0.1$ & $1.1 \pm 3.3$ & $18.4 \pm 7.8$ \\
\hline$\left(\mu g\right.$ chl $\left.a 1^{-1}\right)$ & $0.21 \pm 0.10$ & $0.07 \pm 0.06$ & $0.05 \pm 0.06$ & 0 & $0.11 \pm 0.05$ & $0.05 \pm 0.03$ & \\
\hline \multicolumn{8}{|c|}{ Intermediate biomass region } \\
\hline$\left(\mu g \mathrm{C}^{-1}\right)$ & $50.0 \pm 50.8$ & $36.1 \pm 72.4$ & $0.6 \pm 0.6$ & $9.2 \pm 6.9$ & $0.5 \pm 1.5$ & $1.7 \pm 5.0$ & $19.8 \pm 9.6$ \\
\hline$\left(\mu g\right.$ chl $\left.a 1^{-1}\right)$ & $1.05 \pm 0.63$ & $0.36 \pm 0.63$ & $0.21 \pm 0.21$ & 0 & 0 & 0 & \\
\hline \multicolumn{8}{|c|}{ High biomass region } \\
\hline$\left(\mu g \mathrm{C} \mathrm{l}^{-1}\right)$ & $690.4 \pm 399.3$ & $3 \quad 36.1 \pm 46.4$ & $3.2 \pm 6.2$ & $5.3 \pm 5.2$ & $0.5 \pm 0.8$ & $0.3 \pm 0.9$ & $8.4 \pm 4.7$ \\
\hline$\left(\mu \mathrm{g} \mathrm{chl} \mathrm{a} \mathrm{l}^{-1}\right)$ & $9.73 \pm 6.37$ & $0.92 \pm 1.23$ & 0 & 0 & 0 & 0 & \\
\hline
\end{tabular}


area (Vernet 1992, Moline et al. 1997, Prézelin et al. 2000, Rodriguez et al. 2002).

\section{Comparison of microscopic and chemotaxonomic techniques}

Comparison of phytoplankton characterization by microscopy and chemotaxonomy showed high qualitative agreement, revealing considerable variability of phytoplankton structure along an on/offshore gradient. Both methods showed shifts in dominant microalgae groups among the low, intermediate and high biomass regions, indicating compositional changes along the gradient (Table 4). Microscopy also revealed size-fraction and diatom species shifts. In addition, $\mathrm{C}$ and chl a distribution patterns agree, showing a gradual decrease of phytoplankton standing stock seaward (Fig. 1). However, quantitative comparison of chl a to C concentrations indicated discrepancies among microscopic and chemotaxonomic biomass estimates. Differences were noteworthy for the low biomass region that had a $60 \%$ variability in the relationship between $\mathrm{C}$ and chl a concentrations $\left(\mathrm{R}^{2}=0.40\right)$ (Fig. 5a). Differences were of less importance for the intermediate and high biomass communities, which had a $24 \%$ $\left(\mathrm{R}^{2}=0.76\right)$ and $28 \%\left(\mathrm{R}^{2}=0.72\right)$ variability between both estimates, respectively (Fig. 5b,c). The variability in these correlations, based on mixed assemblages, is due to differences among biomass estimates of individual microalgal groups, as discussed below.

Diatom C to chl a correlation presented high scatter for the low biomass region $\left(\mathrm{R}^{2}=0.20\right)$, and low scatter for the intermediate and high biomass regions $\left(\mathrm{R}^{2}=\right.$ 0.81 and 0.78 , respectively) (Fig. 5d,e,f, Table 4 ). These results indicated that agreement among microscopy and chemotaxonomy for diatom biomass estimation depends on the community under analysis. Diatom chl a biomass was determined from fucoxanthin concentration, which is an ambiguous marker that is also present in other microalgae (Wright \& Jeffrey 1987 , Jeffrey \& Vesk 1997). Thus, contribution of other microalgal classes to fucoxanthin concentration introduces uncertainty in the estimation of the diatom biomass as chl $a$. The uncertainty is higher in the low biomass region, where the phytoplankton assemblage had a mixed composition, and the proportion of non-diatom fucoxanthin might have been considerable. In contrast, diatoms dominated the intermediate and high biomass communities, probably accounting for most of the fucoxanthin concentration and giving reliable biomass estimates.

Therefore, we hypothesize that sharing of the characteristic pigment was the major source of error in our diatom quantification, but that it was of importance only in 1 phytoplankton assemblage. This limitation might be overcome using a pigment matrix factorization method, such as the CHEMTAX program, which takes into account fucoxanthin crossover among diatoms and other microalgal groups. This is indicated by the results of Schlüter et al. (2000) who used this method to quantify diatom chl a biomass, and found good agreement with microscopic $\mathrm{C}$ estimates for a mixed community and a diatom bloom. That study was based on a very accurate estimation of pigment ratios used to initialize the analysis, taking into consideration environmental influence and interspecies changes on pigment ratios (Schlüter et al. 2000). Field studies in the Southern Ocean show limitations of the matrix factorization method, such as lack of diatom contribution at sites where they were observed under the microscope, or unreliable calculated biomass concentrations at some sites, which was attributed to pigment ratios variability (Wright et al. 1996, Rodriguez et al. 2002).

Cryptophyte $\mathrm{C}$ and chl a estimates were closely related for the 3 assemblages analyzed $\left(R^{2}=0.69,0.98\right.$ and 0.98 for low, intermediate and high biomass communities, respectively), suggesting that cryptophyte biomass can be accurately estimated by microscopy and chemotaxonomy (Fig. 5g,h,i, Table 4). Moreover, for all the samples where cryptophyte cells were observed and $\mathrm{C}$ concentrations estimated, alloxanthin was detected and cryptomonad-chl a quantified. This high level of agreement can be ascribed to the wellknown taxonomy of the group (Throndsen 1997) and to the fact that alloxanthin is an unequivocal marker pigment of this class (Jeffrey \& Vesk 1997).

Comparison of these results with those of other studies suggests that sample processing is critical for cryptophyte analysis. Sample fixation with acid Lugol's iodine solution and cell quantification according to the Utermöhl (1958) method are highly recommended for phytoflagellate analysis (Throndsen 1978). These are the methods that we applied, as did Buma et al. (1992) and Rodriguez et al. (2002), who also found good correspondence between microscopy and chemotaxonomy for cryptophyte quantification. In contrast, studies that used epifluorescence microscopy reported no agreement among methods for this class (Gieskes \& Kraay 1983, Booth et al. 1988, Wright et al. 1996, Jeffrey \& Vesk 1997). We consider that these discrepancies may be a consequence of the sample processing used, since cells may be destroyed during sample filtration for epifluorescence analysis.

Chlorophyte biomass was estimated as chl $a$, as derived from chl $b$ concentration, and microscopically, Pyramimonas spp. cells were recognized and their $\mathrm{C}$ biomass estimated (Table 4). Correlations among $\mathrm{C}$ and chl a estimates were significant and high for the low and intermediate biomass communities $\left(\mathrm{R}^{2}=0.66\right.$ 

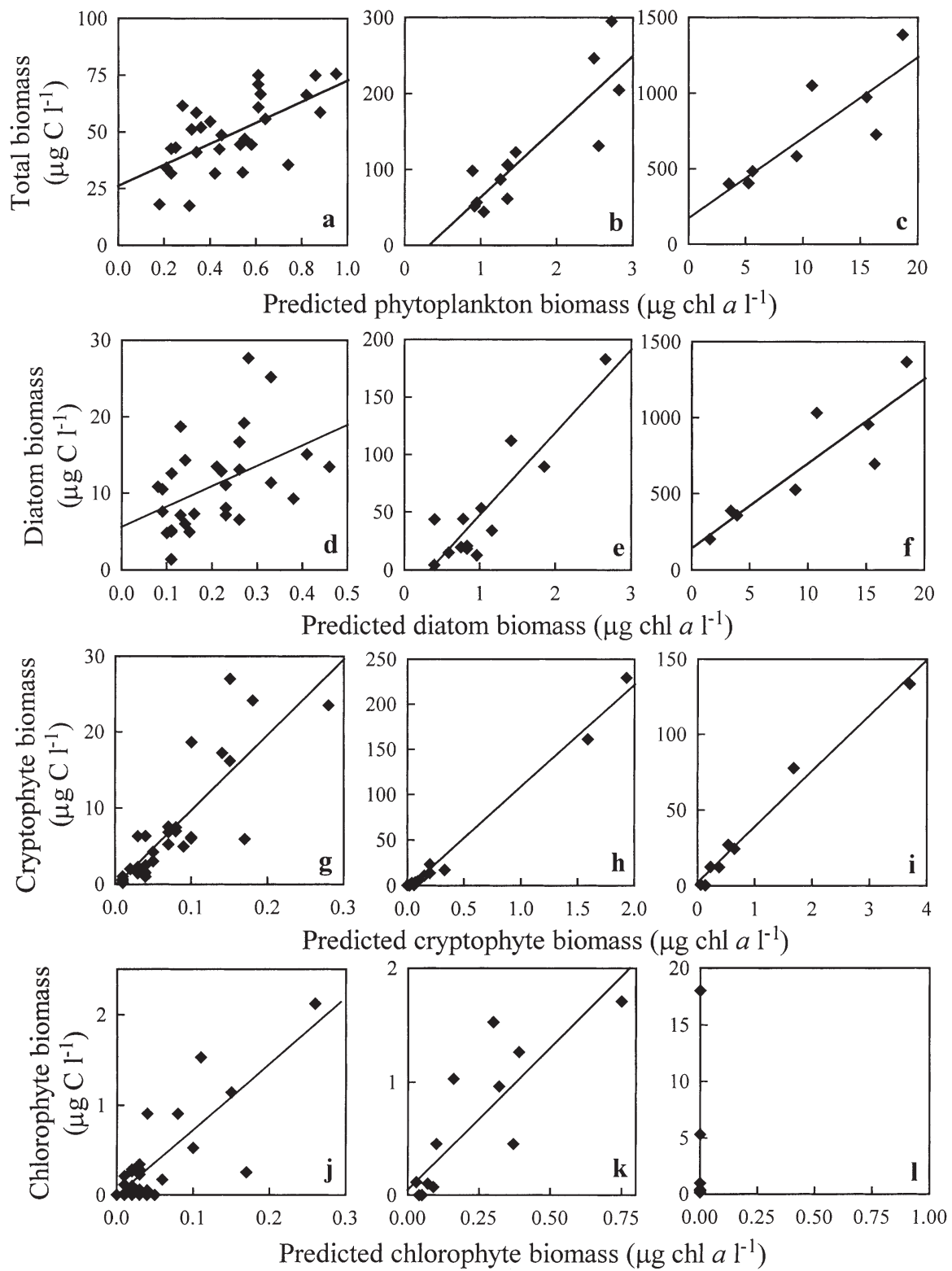

Fig. 5. Biomass of total phytoplankton community and individual microalgal classes estimated as chl a and C concentrations from HPLC pigment data and microscopic measurements, respectively. Regions as in Fig. 1. (a,d,g,j) Low biomass region $(\mathrm{n}=29)$, $(\mathrm{b}, \mathrm{e}, \mathrm{h}, \mathrm{k})$ intermediate biomass region $(\mathrm{n}=13)$ and $(\mathrm{c}, \mathrm{f}, \mathrm{i}, \mathrm{l})$ high biomass region $(\mathrm{n}=8)$. Lines correspond to correlation between biomass estimates. Correlation coefficients are given in the text, $\mathrm{p}<0.01$ throughout

and 0.69 , respectively) (Fig. 5j,k), suggesting that biomass concentrations were accurately estimated using both techniques. These results also suggest that Pyramimonas spp. accounted for most of chlorophyte biomass in these regions. In a few samples, we estimated chl a biomass associated to this group and no Pyramimonas spp. were observed (Fig. $5 \mathrm{j}, \mathrm{k}$ ), indicating that probably small chl $b$-containing cells were present and not recognized under the microscope, as discussed by Buma et al. (1992). Chl $b$ made a non-significant contribution to the chl a to diagnostic pigments multiple regression of the high biomass region (Table 1), and consequently, chlorophyte-chl a was calculated as zero. This result led to an underestimation of chlorophytes in this region as this group was identified in this region by microscopy as representing $0.5 \%$ of the $\mathrm{C}$ biomass (Fig. 5l, Table 4).

The proportion of the chl $b$ accounted for by the 2 classes of chlorophytes, Prasinophyceae and Chlorophyceae, can be approached from the concentration of prasinoxanthin and lutein, respectively, which are in some cases considered as diagnostic pigments of these 
classes (Jeffrey \& Vesk 1997). However, the presence of these pigments is not constant in all members of these classes (Wright et al. 1996, Schlüter et al. 2000); the concentration of these pigments might vary as an adaptational response to light (Prézelin et al. 2000) and lutein might be present in both classes (Jeffrey \& Vesk 1997). Thus, we preferred to limit the analysis to the division level in order to reduce ambiguities and sources of error.

Dinoflagellate C concentrations were estimated microscopically at most stations, whereas chl a biomass based on peridinin concentration was estimated as zero (Table 4). This discrepancy can be partially related to overestimation of $\mathrm{C}$ concentration due to the presence of heterotrophic dinoflagellates that may have been wrongly identified as autotrophic during microscopic examination (Booth 1993), or peridininlacking species may have been present (Millie et al. 1993).

Peridinin, an exclusive marker of these microalgae (Jeffrey \& Vesk 1997), was detected in most samples, confirming the presence of autotrophic representatives. However, it was present in very low concentration (Table 2) and made a non-significant contribution to the chl a to diagnostic pigments multiple regression (Table 1). Problems quantifying dinoflagellates by chemotaxonomy are not restricted to the multiple regression analysis. Rodriguez et al. (2002) used the pigment matrix factorization method to study a nearby northern area of the Western Antarctic Peninsula, during the same year and period as our research, and could not quantify the dinoflagellate biomass. A similar problem was found in equatorial waters by Landry et al. (2000). Both studies concluded that most dinoflagellates must have been peridinin-lacking species. This explanation is the more likely reason for the high dinoflagellate $\mathrm{C}$ biomass quantified in our study (Table 4), and the low peridinin concentration measured throughout the area. Thus, we conclude that there is major uncertainty associated with the use of peridinin as a chemotaxonomic marker of dinoflagellates.

Prymnesiophyte standing stock was estimated as C in samples in which Phaeocystis spp. cells were recognized and as chl a from 19'-hexanoyloxyfucoxanthin concentration. The biomass estimates by both techniques were not consistent (Table 4). In this respect, different problems in both techniques must be considered. First, the diversity of species of this division is high (Buma et al. 1992, Throndsen 1997) and many representatives may have not been recognized microscopically. In addition, biomass estimation by multiple regression is uncertain in as much as 19'-hexanoyloxyfucoxanthin is an equivocal marker of prymnesiophytes (Jeffrey 1997). Moreover, this pigment made a non-significant contribution to the regression analysis of the intermediate and high biomass communities (Table 1).

Chrysophyte $\mathrm{C}$ and chl a concentrations estimated by microscopy and chemotaxonomy were not consistent (Table 4). Pigment composition of this division is not well known (Jeffrey \& Vesk 1997), and although the carotenoid 19'-butanoyloxyfucoxanthin is commonly used as a diagnostic pigment of Pelagophyceae, it is not fully ascribed to this taxon (Wright \& Jeffrey 1987). Otherwise, while diversity of species of this division is high (Throndsen 1997), the only representatives that were recognized under the microscope belonged to Dictyocha spp.

A large quantity of small phytoflagellates $(<20 \mu \mathrm{m})$ could not be taxonomically identified microscopically (Table 4). According to our previous discussion, these flagellates could belong mostly to chrysophytes and prymnesiophytes, taxa that showed disagreement in the estimation by microscopy and chemotaxonomy, and in lower proportion to chlorophytes and cryptophytes that showed a high level of agreement among C and chl a biomass estimates. In general, light microscopy is considered inaccurate for the study of small forms, in particular phytoflagellates, due to problems in sample processing as well as cell enumeration and sizing (Paerl 1978, Hewes et al. 1984, Kuosa 1988, Booth 1993, Bidigare et al. 1996, Schlüter et al. 2000). However, the good agreement found between the microscopic and pigment analysis for cryptophytes and chlorophytes allows us to state that phytoflagellate cells can be well preserved in iodine Lugol's fixed samples, and their enumeration and sizing can be accurately done using sedimentation chambers and an ordinary light microscope. We consider that the major limitation of microscopic studies is the poor taxonomic knowledge of small phytoflagellates from the Southern Ocean, as well as uncertainty in determining their trophic status using ordinary light microscope or possible cell destruction during sample filtration for epifluorescence analysis. Therefore, chemotaxonomic identification may be a more powerful tool to identify these smaller algae, even when pigment interpretation is also difficult (Jeffrey \& Vesk 1997, Jeffrey et al. 1999).

\section{Physiological and ecological considerations}

$$
\text { Cell C quotas }
$$

At present, there is no consensus among different published equations of $\mathrm{C}$ quotas per cell used to convert biovolume measurements on cell biomass. We applied Montagnes et al. (1994) and Montagnes \& Franklin (2001) conversion factors to calculate the C biomass concentrations $\left(\mathrm{C}_{\mathrm{M}}\right)$ discussed up to now (see 


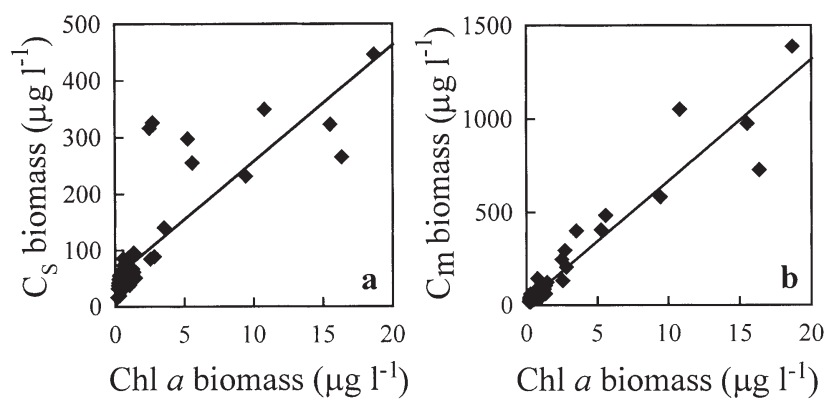

Fig. 6. Relationship between chl a phytoplankton biomass estimated from HPLC pigment data and: (a) total phytoplankton community C estimated using Strathmann (1967) cell content:volume equations $\left(\mathrm{C}_{\mathrm{S}}\right)_{\text {; }}(\mathrm{b})$ total phytoplankton community C estimated using Montagnes \& Franklin (2001) and Montagnes et al. (1994) equations $\left(\mathrm{C}_{\mathrm{M}}\right)$. Solid lines correspond to correlation between biomass estimates for the entire area. $\mathrm{N}=50$ and $\mathrm{p}<0.01$ throughout

'Materials and methods'). However, since factors published by Strathmann (1967) are very frequently used in ecological studies, we calculated phytoplankton C concentration for our data using these factors too $\left(\mathrm{C}_{\mathrm{S}}\right)$. The average $C_{M}$ and $C_{S}$ concentrations calculated for the low biomass regions were similar, but showed great differences for the intermediate and high biomass regions (Table 3 ). For example, average $C_{M}$ concentration was roughly 3 times higher than $C_{S}$ for the high biomass region. This discrepancy reflects the fact that Strathmann (1967) considered diatoms to have large vacuoles and much lower $C$ per cell volume unit than other microalgae; whereas, according to Montagnes et al. (1994) and Montagnes \& Franklin (2001), differences in $\mathrm{C}$ quotas are less pronounced. Consequently, for the intermediate and high biomass communities, in which diatoms made a high contribution to the total biomass stock, differences between both $\mathrm{C}$ estimations became noticeable (Table 3).

The comparison of both $\mathrm{C}$ estimations with chl a biomass estimated from pigment fingerprints allowed some insight into this topic (Fig. 6a,b). The $\mathrm{C}_{\mathrm{M}}$ to $\mathrm{chl} a$ relationship was described in the previous section for each of the 3 regions delimited within the area (Fig. 5a,b,c), but for an easier comparison with $\mathrm{C}_{\mathrm{S}}$ estimates, one plot for the entire area is shown in Fig. 6b. Both C estimates had high variability with chl a concentration for samples with low $\mathrm{C}$ concentration $\left(<100 \mu \mathrm{g} \mathrm{C}^{-1}\right)$. For example, in the low biomass community, chl a concentrations had a $60 \%\left(\mathrm{R}^{2}=0.40\right)$ and $51 \%\left(R^{2}=0.49\right)$ variability with $C_{M}$ and $C_{S}$ estimates, respectively. Possible reasons for this result were discussed in the previous section. In contrast, in the intermediate and high biomass communities, chl a concentrations were strongly related to $\mathrm{C}_{\mathrm{M}}$ estimates $\left(R^{2}=0.81\right.$ and 0.78 , respectively) and more weakly to
$C_{S}$ estimates $\left(R^{2}=0.45\right.$ and 0.50 , respectively). Therefore, in these communities where diatoms accounted for a major proportion of the phytoplanktonic community our results indicate that biomass was more accurately estimated using the cell C:cell volume ratios published by Montagnes et al. (1994) and Montagnes \& Franklin (2001).

Consequently, our results for a mixed natural phytoplankton community, support the conclusion reached by studies on algae cultures that differences among diatom and other microalgae cell quotas are much smaller than earlier believed (Montagnes et al. 1994, Menden-Deuer \& Lessard 2000, Montagnes \& Franklin 2001). This implies that phytoplankton $C$ biomass was greatly underestimated in earlier ecological studies that considered a low $\mathrm{C}$ quota for diatoms. Nevertheless, it needs to be highlighted that the assessment of the different $\mathrm{C}$ quotes by the comparison of $\mathrm{C}$ to $\mathrm{chl} a$ estimations is subject to inaccuracies inherent to both methodologies used, as was discussed in the previous section. On the other hand, since C quotas change with growth conditions and species composition (Strathmann 1967, Thompson et al. 1992, Montagnes et al. 1994, Menden-Deuer \& Lessard 2000), further research on cell $\mathrm{C}$ quotas is necessary to calculate more reliable $\mathrm{C}$ values for Antarctic phytoplankton.

\section{C:chl a ratios}

Biomass estimates presented in the previous sections were used to calculate phytoplankton C:chl a ratios. The range in the estimated $\mathrm{C}: \mathrm{chl}$ a ratios was high,

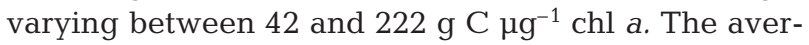

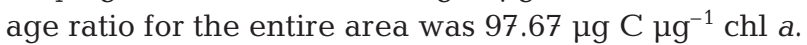
These values are within those previously reported for the Antarctic phytoplankton, which range from 20 to more than $500 \mu \mathrm{g} \mathrm{C} \mathrm{\mu g}^{-1}$ chl a (Smith \& Nelson 1985, Smith \& Sakshaug 1990, Villafañe et al. 1993, Smith et al. 2000).

The 3 regions we delimited within the area showed differences in their C:chl a ratios (Table 5). The average ratio was significantly higher for the low biomass

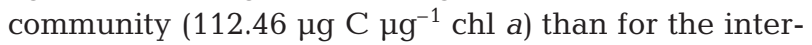
mediate and high biomass communities (72.70 and

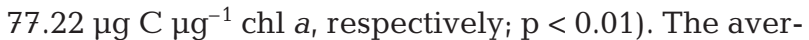
age ratio calculated considering these 2 latter communities together was $74.42 \mu \mathrm{g} \mathrm{C} \mathrm{gg}^{-1}$ chl a. Therefore, we suggest that 2 different $C$ :chl a ratios must be considered for coastal Antarctic phytoplankton, one for low biomass communities $\left(<1 \mu \mathrm{g} \mathrm{chl} \mathrm{a}^{-1}\right)$ and another

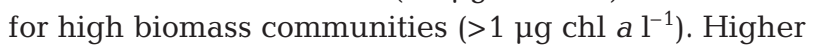
ratios in waters with low autotrophic biomass in comparison to waters with high biomass have been reported for other sites of the Southern Ocean as well 
Table 5. Phytoplankton characteristics: carbon to chl a ratios; carbon primary productivity, growth rates; and chl a-specific productivity. Values \pm SD averaged over the entire study area and in 3 regions differentiated as in Fig. 1

\begin{tabular}{|lcccc|}
\hline & $\begin{array}{c}\text { Carbon to chl a ratio } \\
\left(\mu \mathrm{g} \mathrm{C} \mu \mathrm{g}^{-1} \mathrm{chl} a\right)\end{array}$ & $\begin{array}{c}\text { Primary productivity } \\
\left(\mu \mathrm{g} \mathrm{C} \mathrm{l} \mathrm{d}^{-1}\right)\end{array}$ & $\begin{array}{c}\text { Growth rates } \\
\left(\mathrm{d}^{-1}\right)\end{array}$ & $\begin{array}{c}\text { Chl } a \text {-specific productivity } \\
\left(\mathrm{d}^{-1}\right)\end{array}$ \\
\hline Entire area & $97.67 \pm 40.82$ & $54.58 \pm 85.51$ & $0.28 \pm 0.14$ & $29.81 \pm 15.07$ \\
Low biomass region & $112.46 \pm 43.29$ & $13.14 \pm 6.55$ & $0.25 \pm 0.10$ & $29.92 \pm 9.95$ \\
Intermediate biomass region & $72.70 \pm 22.69$ & $71.02 \pm 73.28$ & $0.40 \pm 0.17$ & $38.41 \pm 23.90$ \\
High biomass region & $77.22 \pm 21.79$ & $202.54 \pm 113.57$ & $0.22 \pm 0.13$ & $16.46 \pm 5.87$ \\
\hline
\end{tabular}

(Hewes et al. 1990, Villafañe et al. 1993, Robins et al. 1995). However, comparison of our results with those reported from other field studies is difficult due to differences in the techniques used. Previous estimations have been mostly based on $\mathrm{C}$ concentrations measured as particulate organic carbon (POC), which may include an unknown quantity of detrital carbon. Even estimations based on microscopic analyses, considered the more accurate method for $\mathrm{C}$ biomass quantification (Reid 1983), are not comparable due to differences in the cell $\mathrm{C}$ quotas applied to convert cell biovolume on $\mathrm{C}$ biomass, as discussed in the previous section.

Previous research in the Western Antarctic Peninsula coast demonstrated a close relationship between chl a concentration of the upper portion of the water column and integrated concentrations with depth, evidencing that chl a remote sensing from satellites is suitable for phytoplankton estimation of this area (Smith et al. 1996). The C:chl a ratios presented here can be used to interpret chl a remote sensing data and for ecosystem dynamic studies in the Southern Ocean.

\section{Growth rate estimates}

Phytoplankton primary production ranged from 4 to $395 \mu \mathrm{g} \mathrm{C}^{-1} \mathrm{~d}^{-1}$ and C-specific accumulation rates (growth rates) ranged from 0.07 to $0.67 \mathrm{~d}^{-1}$ (Table 5). These values are within the range reported in a study performed at the same time as ours, in a nearby northern area of the Western Antarctic Peninsula (Lorenzo et al. 2002). Furthermore, primary production values were associated with differences in $\mathrm{C}$ standing stock (Tables 3 \& 5). Noteworthy is that the high biomass community had very low growth rates $(0.11$ to 0.43$)$, denoting that its high primary production was not the result of high cell activity. This suggests that its high biomass accumulation must have been the result of a previous period of active growth.

Growth rates agreed with the chl a-specific productivity (primary productivity activity:chl a concentration ratio) (Table 5), which is used as indicator of phytoplankton activity when autotrophic biomass is estimated as chl a. Thus, this result indicates that when $\mathrm{C}$ biomass estimates performed microscopically are not available, analysis of phytoplankton dynamics from chl a concentration can yield consistent results. Alternatively, chl a concentration can be converted into $\mathrm{C}$ biomass using the proposed $\mathrm{C}$ :chl a ratios.

The phytoplankton C:chl a ratios were closely related to growth rates (Fig. 7), with higher values found for samples with low growth rates. Similar results have been previously reported for algal cultures and related to the dependence of cell pigment concentration on carbon assimilation rate (Sosik \& Mitchell 1994, Geider et al. 1997). This implies an increasing chl a concentration per cell with growth rate, as a response to a higher energy requirement. Growth rates are the response of phytoplankton to local environmental conditions (Smith \& Sakshaug 1990) and in field studies, differences in C:chl a ratios have been related frequently to the influence of environmental parameters on cell physiology (Smith \& Nelson 1985, Mitchell \& Holm-Hansen 1991, Boyd et al. 1995, Smith et al. 2000).

\section{CONCLUSIONS}

The comparison of the microscopic and HPLC pigment techniques allowed us to evaluate several methodological issues. The high agreement we found between microscopy and chemotaxonomy suggests

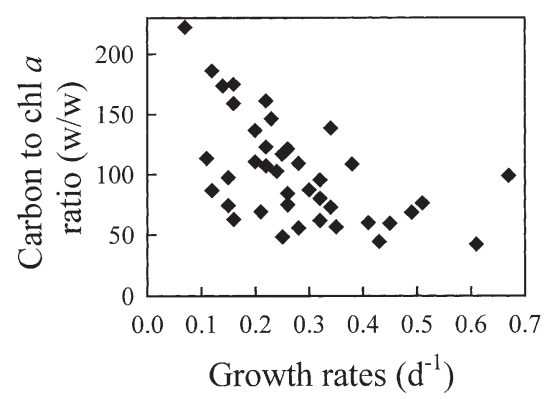

Fig. 7. In situ C: chl a ratios ( $\mu \mathrm{g} \mathrm{C} \mu^{-1} \mathrm{chl}$ a) as a function of phytoplankton community growth rates $\left(\mathrm{d}^{-1}\right)$ based on primary production and $\mathrm{C}$ concentration estimated from microscopic biovolume measurements 
that both methodologies can be used with confidence for the characterization of the phytoplankton community of coastal Antarctic areas. Both methods revealed changes in phytoplankton community composition and biomass along an on/offshore gradient, and they also agreed in the identification and quantification of the dominant groups of different phytoplankton assemblages. Furthermore, the independent examination of each algae class allowed us to go beyond this general comparison and to perform a reliable validation of the results obtained using each technique. The results presented may be helpful to improve the analysis of ecological studies using these techniques and to discern possible sources of error in their results due to methodological limitations.

Microscopy revealed changes in cell abundance, cell size and diatom-specific composition within the area, which is highly valuable information for ecological research that cannot be obtained by pigment analysis. Also, we found good results for cryptophyte and chlorophyte microscopic biomass estimation, allowing us to state that flagellates can be properly preserved with Lugol's iodine and analyzed by light microscopy. However, microscopic analysis failed to identify the composition of other small phytoflagellates, whose taxonomy is poorly known or trophic state cannot be determined. For these groups, chemotaxonomy might certainly be a very valuable tool.

Chemotaxonomic phytoplankton characterization from the pigment data was performed taking into account the ecological and oceanographic context of the area. The multiple regression analyses of pigment concentrations was very useful as an exploratory method, showing major discontinuities in the pigment data, and allowing the recognition of phytoplankton variability within the area and the delimition of different phytoplankton assemblages. We were able to differentiate between the phytoplankton assemblages by their total standing stock, increasing the evidence that changes in phytoplankton communities biomass are associated with compositional shifts.

We propose that to improve the chemotaxonomicpigment data analysis, it is of primary importance to recognize the presence of different phytoplankton assemblages within the area. This conclusion is based on the results of the analysis of some environmental variables which showed that the 3 assemblages distinguished in the area were distributed under homogeneous environmental conditions, and on the microscopic analysis, which showed shifts in the dominant diatoms between these assemblages. Since phytoplankton structure and physiological status are tightly regulated by local water column conditions, it is likely that the distribution of different assemblages within the area would reflect environmental variations. Thus, the independent analysis of different assemblages must contribute to reduce pigment ratios variability due to the environmental conditions and species shifts, which is known to strongly affect the phytoplankton quantification from pigment concentrations.

The high agreement among $\mathrm{C}$ and $\mathrm{chl}$ a estimates demonstrated a reasonable performance of multiple regression pigment data analysis for phytoplankton characterization, constituting a simple method to quantify the main components of the community. However, certain limitations were found. It was not possible to detect the presence of microalgae groups with minor contribution to autotrophic biomass (less than $1 \%$ of $\mathrm{C}$ biomass), nor to accurately estimate the biomass of diatoms when other groups with fucoxanthin were an important component of the community. Pigment data analysis using a matrix factorization method, such as the CHEMTAX program, might provide a solution to these 2 problems. However, its application is not straightforward and previous studies in the Southern Ocean have reported deficiencies in quantifying phytoplankton biomass using this method (Wright et al. 1996, Rodriguez et al. 2002), which are similar to that what were found in this study using the pigment multiple regression analysis. Those studies attributed the deficiencies found to problems in the analysis when the same initial pigments are used for a large area. Thus, due to the high environmental variability and the important changes in phytoplankton composition and diatom species present throughout our study area, a different matrix of initial pigment ratios would be necessary for the analysis of each one of the assemblages differentiated within the area. Improvement of the pigment ratio knowledge is certainly required for the correct application of the matrix factorization method in these different assemblages.

Finally, we conclude that further research is needed to assess the correct application of the chemotaxonomical approach to ecological studies of natural phytoplankton assemblages. The multiple regression analysis presented here was an invaluable tool for a comprehensive analysis of pigment data and community structure.

Acknowledgements. We would like to thank the crew of the RV 'Polar Duke' and Antarctic Support Associates, Inc. for their support during sampling. The members of the LongTerm Ecological Research program provided help and stimulating discussions during the cruise. We would like to thank Jonah Rosenfield and Andrew Greaves for primary production determinations. We thank Irene Schloss for critical comments and suggestions that improved the manuscript. This project was funded by the Office of Polar Programs, National Science Foundation, USA, grant 96-32763 to M.V. I.A.G.'s work was supported by a doctoral fellowship of the Consejo Nacional de Investigaciones Científicas y Técnicas (CONICET), Argentina. This is the Palmer LTER Contribution \#229. 


\section{LITERATURE CITED}

Baker KS, Fraser WR, Hofmann EE, Karl DM and 7 others (1996) The western Antarctic Peninsula region: summary of environmental and ecological processes. In: Ross RM, Hofmann EE, Quetin LB (eds) Foundations for ecological research west of the Antarctic Peninsula. Antarctic Research Series 70. American Geophysical Union, Washington, p 437-448

Bidigare RR, Iriarte JL, Kang SH, Karentz D, Ondrusek ME, Fryxell GA (1996) Phytoplankton: quantitative and qualitative assessments. In: Ross RM, Hofmann EE, Quetin LB (eds) Foundations for ecological research west of the Antarctic Peninsula. Antarctic Research Series 70. American Geophysical Union, Washington, p 173-198

Booth BC (1993) Estimating cell concentration and biomass of autotrophic plankton using microscopy. In: Kemp PF, Sherr BF, Sherr EB, Cole JJ (eds) Handbook of methods in aquatic microbial ecology. Lewis Publishers, Boca Raton, FL, p 199-205

Booth BC, Lewin J, Lorenzen CJ (1988) Spring and summer growth rates of subarctic Pacific phytoplankton assemblages determined from carbon uptake and cell volumes estimated using epifluorescence microscopy. Mar Biol 98: 287-298

Boyd PW, Robinson C, Savidge G, Williams PJ leB (1995) Water column and sea-ice primary production during Austral spring in the Bellingshausen Sea. Deep-Sea Res II 42:1177-1200

Buma AGJ, Treguer P, Kraay GW, Morvan J (1990) Algal pigment patterns in different water masses of the Atlantic sector of the Southern Ocean during fall 1987. Polar Biol 11:55-62

Buma AGJ, Gieskes WWC, Thomsen HA (1992) Abundance of Cryptophyceae and chlorophyll $b$-containing organisms in the Weddell-Scotia Confluence area in the spring of 1988. Polar Biol 12:43-52

Claustre H (1994) The trophic status of various oceanic provinces as revealed by phytoplankton pigment signatures. Limnol Oceanogr 39:1206-1210

Dierssen HM, Vernet M, Smith RC (2000) Optimizing models for remotely estimating primary production in Antarctic coastal waters. Antarct Sci 12:20-32

Geider RJ, MacIntyre HL, Kana TM (1997) Dynamic model of phytoplankton growth and acclimation: responses of the balanced growth rate and the chlorophyll a: carbon ratio to light, nutrient-limitation and temperature. Mar Ecol Prog Ser 148:187-200

Gieskes WWC, Kraay GW (1983) Dominance of Cryptophyceae during the phytoplankton spring bloom in the North Sea detected by HPLC analysis of pigments. Mar Biol 75:179-185

Gieskes WWC, Kraay GW, Nontji A, Setiapermana D, Sutomo (1988) Monsoonal alteration of a mixed and a layered structure in the phytoplankton of the euphotic zone of the Banda Sea (Indonesia): a mathematical analysis of algal pigment fingerprints. Neth J Sea Res 22:123-137

Havens KE, Steinman AD, Carrick HJ, Louda JW, Winfree NM, Baker EW (1999) Comparative analysis of lake periphyton communities using high performance liquid chromatography (HPLC) and light microscope counts. Aquat Sci 61:307-322

Hewes CD, Reid FMH, Holm-Hansen O (1984) The quantitative analysis of nanoplankton: a study of methods. J Plankton Res 6:601-613

Hewes CD, Sakshaug E, Reid FMH, Holm-Hansen (1990) Microbial autotrophic and heterotrophic eucaryotes in
Antarctic waters: relationship between microbial carbon and chlorophyll, adenosin triphosphate, and particulate organic matter. Mar Ecol Prog Ser 63:27-35

Hillebrand H, Dürselen CD, Kirschtel D, Pollingher U, Zohary $\mathrm{T}$ (1999) Biovolume calculation for pelagic and benthic microalgae. J Phycol 35:403-424

Jacques G, Panouse M (1991) Biomass and composition of size fractionated phytoplankton in the Weddell-Scotia Confluence area. Polar Biol 11:315-328

Jeffrey SW, Vesk M (1997) Introduction to marine phytoplankton and their pigment signatures. In: Jeffrey SW, Mantoura RFC, Wright SW (eds) Phytoplankton pigments in oceanography: guidelines to modern methods. UNESCO, Paris, p 19-36

Jeffrey SW, Wright SW, Zapata M (1999) Recent advances in HPLC analysis of phytoplankton. Mar Freshw Res 50: $879-896$

Kuosa H (1988) Enumeration of autotrophic and heterotrophic flagellates in Baltic Sea samples - a comparison of microscopical methods. Arch Hydrobiol Beih Ergebn Limnol 31: 301-306

Lami A, Guilizzoni P, Ruggiu D, Polli B, Simona M, Barbieri A (1992) Role of pigments on algal communities and photosynthesis. Aquat Sci 54:321-330

Landry MR, Constantinou J, Latasa M, Brown SL, Bidigare RR, Ordrusek ME (2000) Biological response to iron fertilization in the eastern equatorial Pacific (IronEx II). III. Dynamics of phytoplankton growth and microzooplankton grazing. Mar Ecol Prog Ser 201:57-72

Lorenzo LM, Arbones B, Figueiras FG, Tilstone GH, Figueroa FL (2002) Photosynthesis, primary production and phytoplankton growth rates in Gearlache and Bransfield Straits during Austral summer: cruise FRUELA 95. Deep-Sea Res II 49:707-721

Mackey MD, Mackey DJ, Higgins HW, Wright SW (1996) CHEMTAX - a program for estimating class abundances from chemical markers: application to HPLC measurements of phytoplankton. Mar Ecol Prog Ser 144:1441-1468

Marty JC, Chiavérini J, Pizay MD, Avril B (2002) Seasonal and interannual dynamics of nutrients and phytoplankton pigments in the western Mediterranean Sea at the DYFAMED time-series station (1991-1999). Deep-Sea Res II 49:1965-1985

Menden-Deuer S, Lessard EJ (2000) Carbon to volume relationships for dinoflagellates, diatoms, and other protist plankton. Limnol Oceanogr 45:569-579

Menden-Deuer S, Lessard EJ, Satterberg J (2001) Effect of preservation on dinoflagellate and diatom cell volume and consequences for carbon biomass predictions. Mar Ecol Prog Ser 222:41-50

Millie DF, Paerl HW, Hurley JP (1993) Microalgal pigment assessment using high-performance liquid chromatography: a synopsis of organismal and ecological applications. Can J Fish Aquat Sci 50:2513-2527

Mitchell BG, Holm-Hansen O (1991) Observations and modeling of the Antarctic phytoplankton crop in relation to mixing depth. Deep-Sea Res 38:981-1007

Moline MA, Prézelin BB, Schofield O, Smith RC (1997) Temporal dynamics of coastal Antarctic phytoplankton: environmental driving forces and impact of a 1991/92 summer diatom bloom on the nutrient regimes. In: Battaglia $B_{\text {, }}$ Valencia J, Walton DWH (eds) Antarctic communities species, structure and survival. Cambridge University Press, New York, p 67-72

Moline MA, Claustre H, Frazer TK, Grzymski J, Schofield O, Vernet M (2000) Changes in phytoplankton assemblages along the Antarctic Peninsula and potential implications 
for the Antarctic food web. In: Davison W, HowardWilliams C, Brody P (eds) Antarctic ecosystems: model for wider ecological understanding. Caxton Press, Christchurch, p 263-271

Montagnes DJS, Franklin DJ (2001) Effect of temperature on diatom volume, growth rate, and carbon and nitrogen content: reconsidering some paradigms. Limnol Oceanogr 46:2008-2018

Montagnes DJS, Berges JA, Harrison PJ, Taylor FJR (1994) Estimating carbon, nitrogen, protein, and chlorophyll a from volume in marine phytoplankton. Limnol Oceanogr 39:1044-1060

Paerl HW (1978) Effectiveness of various counting methods in detecting viable phytoplankton. NZ J Mar Freshw Res 12: 67-72

Prézelin BB, Hofmann EE, Mengelt C, Klinck JM (2000) The linkage between Upper Circumpolar Deep Water (UCDW) and phytoplankton assemblages on the west Antarctic Peninsula continental shelf. J Mar Res 58:165-202

Priddle J, Smetacek V, Bathmann U (1992) Antarctic marine primary production, biogeochemical carbon cycles and climatic change. Phil Trans R Soc Lond B 338:289-297

Reid FMH (1983) Biomass estimation of components of the marine nanoplankton and picoplankton by the Utermöhl settling technique. J Plankton Res 5:235-252

Robins DB, Harris RP, Bedo AW, Fernández E, Fileman TW, Harbour DS, Head RN (1995) The relationship between suspended particulate material, phytoplankton and zooplankton during the retreat of the marginal ice zone in the Bellinghausen Sea. Deep-Sea Res II 42:1137-1158

Rodriguez F, Varela M, Zapata M (2002) Phytoplankton assemblages in the Gearlache and Bransfield Straits (Antarctic Peninsula) determined by light microscopy and CHEMTAX analysis of HPLC pigment data. Deep-Sea Res II 49:723-747

Ross RM, Quetin LB, Baker KS, Vernet M, Smith RC (2000) Growth limitation in young Euphausia superba under field conditions. Limnol Oceanogr 45:31-43

Schlüter L, Mohlenberg F, Havskum H, Larsen S (2000) The use of phytoplankton pigments for identifying and quantifying phytoplankton groups in coastal areas: testing the influence of light and nutrients on pigment/chlorophyll a ratios. Mar Ecol Prog Ser 192:49-63

Smith WO, Nelson DM (1985) Phytoplankton bloom produced by receding ice edge in the Ross Sea: spatial coherence with the density field. Science 227:163-166

Smith WO Jr, Sakshaug E (1990) Polar phytoplankton. In: Smith WO (ed) Polar oceanography, Part B: chemistry, biology, and geology. Academic Press, San Diego, p 477-525

Smith RC, Dierssen HM, Vernet M (1996) Phytoplankton biomass and productivity in the western Antarctic Peninsula region. In: Ross RM, Hofmann EE, Quetin LB (eds) Foundations for ecological research west of the Antarctic Peninsula. Antarctic Research Series 70. American Geophysical Union, Washington, p 333-356

Smith WO Jr, Mara J, Hiscock MR, Barber RT (2000) The seasonal cycle of phytoplankton biomass and primary productivity in the Ross Sea, Antarctica. Deep-Sea Res II 47: 3119-3140

Sosik HM, Mitchell BG (1991) Absorption, fluorescence, and quantum yield for growth in nitrogen-limited Dunaliella tertiolecta. Limnol Oceanogr 36:910-921
Sosik HM, Mitchell BG (1994) Effects of temperature on growth, light absorption, and quantum yield in Dunaliella tertiolecta (Chlorophyceae). J Phycol 30:833-840

Strathmann RR (1967) Estimating the organic carbon content of phytoplankton from cell volume or plasma volume. Limnol Oceanogr 12:411-418

Tester PA, Geesey ME, Guo C, Paerl HW, Millie DF (1995) Evaluating phytoplankton dynamics in the Newport River estuary (North Carolina, USA) by HPLC-derived pigment profiles. Mar Ecol Prog Ser 124:237-245

Thompson PA, Guo M, Harrison PJ (1992) Effects of variation in temperature. I. On the biochemical composition of eight species of marine phytoplankton. J Phycol 28:481-488

Throndsen J (1997) The planktonic marine flagellates. In: Tomas CR (ed) Identifying marine phytoplankton. Academic Press, San Diego, p 591-730

Throndsen J (1978) Preservation and storage. In: Sournia A (ed) Phytoplankton manual. Monographs on oceanographic methodology 6. UNESCO, Paris, p 69-74

Utermöhl H (1958) Zur Vervollkommnung der quantitativen Phytoplankton Methodik. Mitt Int Ver Theor Angew Limnol 9:1-38

Van Leeuwe MA, Timmermans KR, Witte HJ, Kraay GW, Veldhuis MJW, de Baar HJW (1998) Effects of iron stress on chromatic adaptation by natural phytoplankton communities in the Southern Ocean. Mar Ecol Prog Ser 166: $43-52$

Varela M, Fernández E, Serret P (2002) Size-fractionated phytoplankton biomass ad primary production in the Gearlache and south Bransfield Straits (Antarctic Peninsula) in the austral summer 1995-1996. Deep-Sea Res II 49:749-768

Vernet M (1992) RACER: predominance of cryptomonads and diatoms in Gearlache Strait. Antarct J US 27:157-158

Vernet M, Baker KS (1996) Palmer Long-Term Ecological Research (LTER): annual January cruise for 1996 (PD 96-1). Antarct J US 31:157-159

Villafañe VE, Helbling EW, Holm-Hansen O (1993) Phytoplankton around Elephant Island, Antarctica: distribution, biomass and composition. Polar Biol 13:183-191

Villafañe VE, Helbling EW, Holm-Hansen O (1995) Spatial and temporal variability of phytoplankton biomass and taxonomic composition around Elephant Island, Antarctica, during the summers of 1990-1993. Mar Biol 123: 677-686

Von Bröckel K (1981) The importance of nanoplankton within the pelagic Antarctic ecosystem. Kiel Meeresforsch Sonderh 5:61-67

Waters KJ, Smith RC (1992) Palmer LTER: a sampling grid for the Palmer LTER program. Antarct J US 27:236-238

Wright SW, Jeffrey SW (1987) Fucoxanthin pigment markers of marine phytoplankton analyzed by HPLC and HPTLC. Mar Ecol Prog Ser 38:259-266

Wright SW, Jeffrey SW, Mantoura RFC, Llewellyn CA, Bjørnland T, Repeta D, Welschmeyer N (1991) Improved HPLC method for the analysis of chlorophylls and carotenoids from marine phytoplankton. Mar Ecol Prog Ser 77:183-196

Wright SW, Thomas DP, Marchant HJ, Higgins HW, Mackey MD, Mackey DJ (1996) Analysis of phytoplankton of the Australian sector of the Southern Ocean: comparisons of microscopy and size frequency data with interpretations of pigment HPLC data using the 'CHEMTAX' matrix factorization program. Mar Ecol Prog Ser 144:285-298

Submitted: April 26, 2002; Accepted: August 26, 2002

Proofs received from author(s): January 6, 2003 